\title{
Possible Influences of Water Loss and Polyphenol Oxidase Activity on Anthocyanin Content and Discoloration in Fresh Ripe Strawberry (cv. Oso Grande) During Storage at $1{ }^{\circ} \mathrm{C}$
}

M. CECILA N. NUNES, JEFFrEY K. BRECHT, AlCinA M.M.B. MORAIS, AND STEVE A. SARGENT

\begin{abstract}
Fresh 'Oso Grande' strawberries wrapped in polyvinyl chloride stretch film lost $0.7 \%$ of their initial weight during storage for $8 \mathrm{~d}$ at $1{ }^{\circ} \mathrm{C}$, whereas unwrapped fruit lost $11 \%$. Greater water loss was associated with darker and less red fruit, lower concentrations of anthocyanins and other soluble phenolics, and higher polyphenol oxidase (PPO) activity. Anthocyanin degradation and oxidation of soluble phenolic compounds, caused possibly by increased PPO activity as a result of water loss, contributed to the development of strawberry surface browning during storage. Proper handling to reduce water loss during postharvest operations should be used to maintain acceptable color of strawberries during shipping and retailing.

Keywords: weight loss, color, soluble phenolic content, browning index, anthocyanin degradation index
\end{abstract}

\section{Introduction}

$\mathrm{C}$ olor is one of the most important factors in fresh strawberry appearance and greatly contributes to fruit quality. As with other fruits, discoloration of strawberries is undesirable because it results in the fruit losing fresh color and glossiness. The bright red color of strawberry fruit is due to the presence of anthocyanin pigments in the fruit epidermis and cortex. Pelargonidin-3-glucoside (PGN) and cyanidin-3-glucoside were identified as the main monomeric anthocyanins of strawberry fruit. PGN comprises $80 \%$ of the total anthocyanin content in strawberry while cyanidin-3glucoside is present in smaller amounts (Bakker and others 1994). Strawberry pigments, like other anthocyanins, are relatively unstable and may easily lose their bright color due to degradation by oxidative enzymes such as polyphenol oxidase (PPO), which is primarily localized in the cortex of strawberry fruit with the anthocyanins and other phenolics (López-Serrano and Ros Barceló 2001). In fact, browning in fruits is primarily attributed to PPO activity, which is able to act on phenolic compounds in the presence of oxygen (Nicolas and others 1994). PPO catalyzes the hydroxylation of monophenolics, leading to the formation of $o$ diphenol compounds and to the oxidation of $o$-dihydroxy compounds to quinones. The quinones subsequently undergo polymerization, producing characteristic yellow to brown colors in the fruit tissue (Mayer and Harel 1979; Spanos and Wrolstad 1992). Changes in anthocyanins seem to be one of the causes of fruit browning, and their degradation is the result of coupled oxidation by PPO in the presence of other phenolic compounds

MS 20040160 Submitted 3/11/04, Revised 6/8/04, Accepted 9/7/04. Authors Nunes, Brecht, and Sargent are with Horticultural Sciences Dept., Univ. of Florida, 717 Hull Rd., P.O. Box 110690, Gainesville, FL 32611-0690, U.S.A. Author Morais is with Escola Superior de Biotecnologia, Univ. Católica Portuguesa, Porto, Portugal. Direct inquiries to author Brecht (E-mail: jkb@ifas.ufl.edu).
(Wesche-Ebeling and Montgomery 1990; Kader and others 1999; Jiang 2000; Zhang and others 2000). These authors suggested that oxidation and polymerization reactions of anthocyanins with PPOproduced quinones and intermediate oxidation products, rather than direct PPO action on anthocyanins, may play a role in anthocyanin losses and color changes in processed fruits. However, little is known about the development of superficial browning in fresh strawberries during refrigerated storage.

It has been reported that both unripe and ripe strawberries continue red color development in storage as ripening progresses (Sacks and Shaw 1993; Miszczak and others 1995). However, only small increases in anthocyanin content were measured in ripe strawberries stored at 5 or $10^{\circ} \mathrm{C}$ (Kalt and others 1993; Miszczak and others 1995). In previous studies (Nunes and others 1995a, 1995b), we observed that the darkening of stored, ripe strawberries appeared to be related to greater water loss by the fruit. In a study using litchi fruit, Jiang and $\mathrm{Fu}$ (1999b) reported that postharvest browning of the fruit results from desiccation of the pericarp and that oxidation of both anthocyanins and other phenolics is related to PPO activity. Therefore, in this study, fresh, ripe strawberries were stored either wrapped with a vapor barrier polyvinyl chloride (PVC) film or not wrapped to evaluate the differences in color due to water loss during storage. 'Oso Grande' strawberry was used in this study because this cultivar develops a particularly dark, reddish-brown color during storage that is more accentuated than in 'Chandler' or 'Sweet Charlie' strawberry cultivars (Nunes 1995). López-Serrano and Ros Barceló (2001) also reported that the color stability of processed 'Oso Grande' strawberries was less than that of 'Chandler' strawberries.

The objective of this study was to evaluate the color changes in wrapped and unwrapped fresh strawberries during storage in darkness at $1{ }^{\circ} \mathrm{C}$, and the possible influence of PPO activity on anthocyanin content and development of browning during storage. 


\section{Material and Methods}

\section{Plant material and storage conditions}

'Oso Grande' strawberries were obtained from a commercial grower near Floral City, Fla., U.S.A. Preliminary experiments were done using fruit from 2 harvests made in 1994. The experiments were repeated twice in 1995, and the results reported here are for fruit from those latter harvests. In each case, fruit with calyxes intact were harvested in the morning, packed in fiberboard flats containing 12 plastic mesh pint baskets of strawberries, removed from the field with minimal delay after harvest, and transported from Floral City to the laboratory in Gainesville within approximately 2 h. Fully red, ripe fruit were selected for uniformity of color development and freedom from defects, grouped into replicate samples of 10 fruit, weighed, and redistributed into plastic pint baskets. To avoid significant losses of moisture from the fruit during storage, half of the baskets were wrapped with a 0.0181-mm-thick PVC film (W44-75, RJR FilmCo, Aurora, Ohio, U.S.A.; Talasila and others 1995). In our previous work with strawberries (Nunes and others 1998), we showed that this film effectively controls water loss while maintaining an average package atmosphere at $1^{\circ} \mathrm{C}$ of $19 \% \mathrm{O}_{2}$ and $0.8 \% \mathrm{CO}_{2}$. These modest changes in $\mathrm{O}_{2}$ and $\mathrm{CO}_{2}$ levels from normal atmospheric levels preclude the possibility of a modified atmosphere effect on the strawberry color. The remaining baskets were used as controls (unwrapped). The baskets were then placed in a controlled temperature room for $8 \mathrm{~d}$ at $1{ }^{\circ} \mathrm{C}$ and $90 \%$ to $95 \%$ relative humidity (RH). Four replicate samples of 10 fruit each per treatment were removed after $0,2,4,6$, and $8 \mathrm{~d}$ in storage. After conditioning for $4 \mathrm{~h}$ at room temperature $\left(22 \pm 2{ }^{\circ} \mathrm{C}\right)$, physical and chemical determinations were performed.

\section{Weight loss}

Samples of 10 fruit were weighed before and after each storage period, and weight loss was calculated. Because of differences in water loss between wrapped and unwrapped fruit, the concentrations of the chemical constituents were expressed in terms of dry weight (DW). The DW was determined by drying a weighed aliquot of homogenized fruit tissue representing each 10 -fruit sample at $70{ }^{\circ} \mathrm{C}$ for $6 \mathrm{~d}$ and reweighing.

\section{Color assessment}

Fruit surface color was measured with a hand-held tristimulus reflectance colorimeter (Model CR-200b, Minolta Corp., Ramsey, N.J., U.S.A.). Color was recorded using the CIE $L^{*} a^{*} b^{*}$ uniform color space (CIELab), where $L^{*}$ indicates lightness, $a^{*}$ indicates chromaticity on a green (-) to red (+) axis, and $b^{*}$ chromaticity on a blue (-) to yellow (+) axis. Numerical values of $a^{*}$ and $b^{*}$ were converted into hue angle $\left(\mathrm{H}^{\circ}=\tan ^{-1} b^{*} / a^{*}\right)$ and chroma $\left[\mathrm{C}=\left(a^{* 2}+b^{* 2}\right)^{1 / 2}\right]$ (Francis 1980).

\section{Total anthocyanins}

Four replicate samples of 10 fruit per treatment were homogenized in a laboratory blender at high speed for $2 \mathrm{~min}$. Aliquots $(2.00 \mathrm{~g})$ of homogenized strawberry fruit tissue were mixed in $18 \mathrm{~mL}$ of $0.5 \%(\mathrm{v} /$ v) $\mathrm{HCl}$ in methanol and held for $1 \mathrm{~h}$ at $4{ }^{\circ} \mathrm{C}$ to extract the pigment. The flocculate was removed by filtering the extract through a single layer of facial tissue and absorbance of the resulting clear liquid containing the pigments was measured at $520 \mathrm{~nm}$ (maximum absorbance for anthocyanins). Pigment content was calculated using the following formula: $A_{520} \times$ dilution factor $\times$ [molecular weight (MW) of PGN/molar extinction coefficient] where MW of $\mathrm{PGN}=433.2$ and the molar extinction coefficient $=2.908 \times 10^{4}$. Results were expressed as $\mathrm{mg} / 100$ g DW of PGN (Spayd and Morris 1981).

\section{Total soluble phenolics}

Total soluble phenolic compounds were measured using the Folin-Ciocalteu reagent (Folin and Ciocalteu 1927; Singleton and Rossi 1965). Aliquots $(0.50 \mathrm{~mL})$ of clear strawberry juice were diluted in 9.5 $\mathrm{mL}$ deionized water, and to $1 \mathrm{~mL}$ of the resulting solution was added $5 \mathrm{~mL}$ of diluted (1:9) Folin-Ciocalteu reagent. Between 0.5 and $8 \mathrm{~min}$ after addition of the Folin-Ciocalteu reagent, $4 \mathrm{~mL}$ of sodium carbonate solution $(0.075 \mathrm{~g} / \mathrm{mL})$ was added. After $1 \mathrm{~h}$ at $30^{\circ} \mathrm{C}$ plus $1 \mathrm{~h}$ in ice $\left(0^{\circ} \mathrm{C}\right)$, the absorbance of the solution was measured at $760 \mathrm{~nm}$. Gallic acid was used as the standard, and the concentration of total soluble phenolics was expressed as $\mathrm{mg} / 100 \mathrm{~g}$ fruit DW.

\section{Polyphenol oxidase (PPO) activity}

Acetone powder was prepared by extracting $20 \mathrm{~g}$ of strawberry tissue from homogenate with $300 \mathrm{~mL}$ of cold acetone that had been held at $-25^{\circ} \mathrm{C}$. The acetone powder $(100 \mathrm{mg})$ was dissolved in $50 \mathrm{~mL}$ of $0.1 \mathrm{M}$ citric acid- $0.2 \mathrm{M}$ phosphate buffer ( $\mathrm{pH}$ 6.2) and filtered through Whatman $\mathrm{Nr} 4$ filter paper. Absorbance of the filtrate at $420 \mathrm{~nm}$ was measured $1 \mathrm{~min}$ after the addition of $1 \mathrm{~mL}$ of $0.1 \mathrm{M}$ catechol. The results were expressed in units of PPO activity/g fruit DW. One unit of PPO activity was defined as an increase of 0.1 absorbancy unit per min at $420 \mathrm{~nm}$ (Flurkey and Jen 1978).

\section{Browning index (BI) and anthocyanin degradation index (ADI)}

A 50-g sample of frozen strawberries from each replicate was homogenized in a laboratory blender at high speed for $2 \mathrm{~min}$. The homogenates were centrifuged at $800 \times g$ for $25 \mathrm{~min}$ at $4{ }^{\circ} \mathrm{C}$, filtered through Whatman $\mathrm{Nr} 4$ filter paper, and the absorbance of the resulting clear juice was measured immediately to determine the BI and ADI (Wrolstad 1976). The BI was measured as the absorbance of the strawberry juice at $420 \mathrm{~nm}$, the maximum absorbance wavelength for polymeric pigments (that is, tannins). Higher absorbance at $420 \mathrm{~nm}$ indicates greater browning of the sample. The ADI was determined by the ratio between absorbance at $520 \mathrm{~nm}$ (maximum absorbance for anthocyanins) and absorbance at $420 \mathrm{~nm}$. Lower numerical values of the ratio correspond to fruit with greater browning, and higher values correspond to fresher-appearing fruit with less browning.

\section{Statistical analysis}

The statistical analysis system computer package (SAS Inst. 1982) was used for analysis of the data from these experiments. Data from the 2 harvests in 1995 were combined and analyzed simultaneously as initial statistical analysis showed no difference between harvests. The treatments were arranged in a factorial design consisting of 4 storage times $(2,4,6$, and $8 \mathrm{~d}) \times 2$ packaging treatments (wrapped and unwrapped) $\times 4$ replicate samples of 10 fruit; plus 4 additional samples for time zero. Data were analyzed by analysis of variance and significant differences between treatments were detected using the least significant difference at the $5 \%$ level of significance.

\section{Results and Discussion}

\section{Weight loss}

The weight loss of the strawberries increased with storage time, particularly in unwrapped strawberry samples (data not shown). After $8 \mathrm{~d}$ in storage, wrapped strawberries lost about $0.7 \%$ of their weight while unwrapped strawberries lost about $11 \%$ of the initial weight $(P=0.0001)$. In our previous work (Nunes 1995; Nunes and others 1995b), 'Chandler,' 'Oso Grande,'and 'Sweet Charlie' strawberries wrapped in W44-75 film showed similar behavior in terms of 
weight loss during storage at $1{ }^{\circ} \mathrm{C}$. The loss of water from the fruit had a negative effect on the visual appearance, resulting in superficial shriveling and less bright color.

\section{Color}

Even when harvested fully red, strawberries continue to slowly change color and darken during storage (Kalt and others 1993; Sacks and Shaw 1993; Miszczak and others 1995). During storage, the $L^{*}$ value tended to decrease in both wrapped and unwrapped fruit (Figure 1). However, unwrapped strawberries were significantly darker (lower $L^{*}$ value) than wrapped fruit throughout storage $(P=0.0001)$. Therefore, the lower $L^{*}$ value was related to the development of the dark red color on the fruit surface.

The hue value changed little in unwrapped strawberries, and the value after $8 \mathrm{~d}$ of storage was not significantly different from the initial hue value (Figure 1). Hue value increased significantly in wrapped strawberries during the 1 st $2 \mathrm{~d}$ of storage, declined between days 2 and 6 , then increased again. Again, a significant difference in hue value $(P=0.0001)$ was found between wrapped and unwrapped samples after $8 \mathrm{~d}$ in storage. The inconsistent changes in the hue value of the strawberries during storage was probably a consequence of the complex color changes involving both the orange to red anthocyanins and the yellow to brown polymeric pigments.

Chroma increased between 0 and $2 \mathrm{~d}$ storage for wrapped samples then remained constant during the rest of the storage period. In unwrapped samples, the chroma remained unchanged for the 1 st $4 \mathrm{~d}$ storage then decreased slowly (Figure 1). These results indicate a decrease in the color intensity or color purity of the fruit during $8 \mathrm{~d}$ storage in the unwrapped samples $(P=0.0001)$. This change was possibly due to the greater water loss and the consequent desiccation of the surface of unwrapped fruit during storage. Miszczak and others (1995) observed a pronounced decline in the chroma of red 'Kent' strawberries stored for $10 \mathrm{~d}$ under conditions $\left(15^{\circ} \mathrm{C}\right.$ and $75 \% \mathrm{RH}$ ) at which water loss would have been substantial. Sacks and Shaw (1993) also reported that strawberries darkened slowly during storage at $0{ }^{\circ} \mathrm{C}$. Finally, Kalt and others (1993), in a study using 'Blomidon' strawberries, observed that fruit harvested full red darkened during storage and appeared overripe.

\section{Total anthocyanins}

Total anthocyanins, expressed in terms of PGN, the major pigment in strawberry (Baker and others 1994), decreased by about $43 \%$

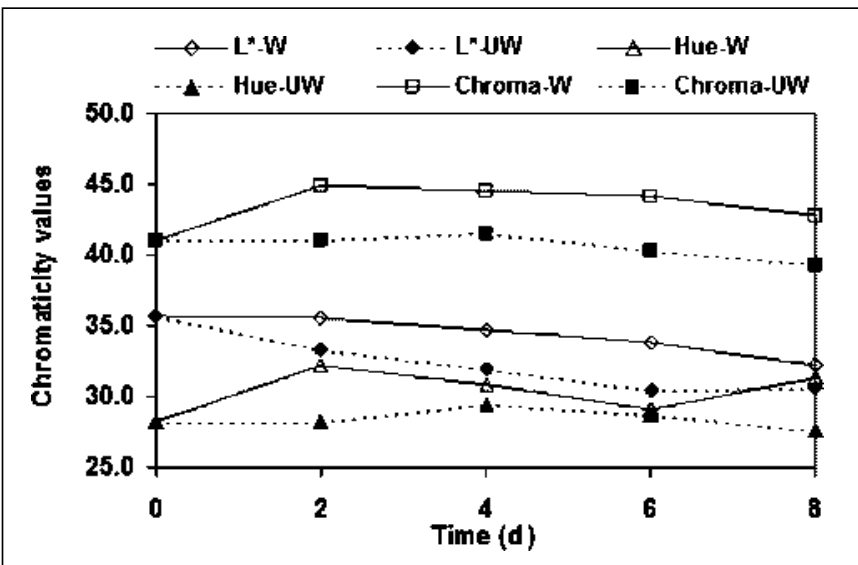

Figure 1-Changes in chromaticity values $\left(L^{*}\right.$, hue and chroma) of strawberry fruit stored at $1^{\circ} \mathrm{C}$ for $8 \mathrm{~d}$. $\mathrm{W}=$ wrapped, UW = unwrapped. $\operatorname{LSD}_{0.05}\left(L^{*}=0.70\right.$, hue $=0.99$, chroma $=0.94$ ) in unwrapped samples, whereas in wrapped fruit anthocyanin content showed no significant changes during $8 \mathrm{~d}$ of storage (Figure 2). It is possible that the great loss of moisture observed in the unwrapped fruit might have contributed, along with oxidative mechanisms, to degradation of the pigments and/or to changes in the anthocyanin pigments structure during storage. Considering that a loss of $6 \%$ in the weight of strawberry makes the fruit unmarketable because of an unacceptable appearance (Robinson and others 1975), we may assume that the magnitude of water loss in the unwrapped strawberries after $8 \mathrm{~d}$ storage might have induced physiological stress and accelerated the senescence of the fruit. Water loss leads to membrane disintegration and leakage of cellular content (Ben-Yehoshua and Rodov 2003) and, thus, could have contributed to the changes in the fruit anthocyanin content. It appears that although anthocyanins accumulate during ripening, they can decrease during storage of strawberries harvested full red if water loss is not controlled, possibly owing to both a decrease in synthesis and increase in degradation (Cheng and Breen 1991), which involves coupled oxidation with other phenolics to produce insoluble compounds (Wesche-Ebeling and Montgomery 1990). Several other enzymatic (PPO-related) and nonenzymatic factors such as ascorbic acid oxidation (Jackman and others 1987), changes in pH and sugar content (Holcroft and Kader 1999), and presence of other phenolics (Kader and others 1997, 1999; Wesche-Ebeling and Montgomery 1990), along with loss of moisture, might have contributed to the decrease in anthocyanin content of strawberries during storage. For example, while ascorbic acid may stabilize anthocyanins (Jackman and other 1987) and react with the $o$-quinones formed during degradation of phenols, preventing the formation of brown pigments (Nicolas and others 1994), it seems that the reaction between the anthocyanins and the compounds formed by the destruction of ascorbic acid may also contribute to anthocyanin degradation (Jackman and others 1987). Oxidation of ascorbic acid was previously attributed to the loss of moisture in unwrapped 'Oso Grande' strawberries during storage (Nunes and others 1998). Because strawberry fruit have a higher content of total ascorbic acid (Bender 1978), anthocyanins, and PPO (López-Serrano and Barceló 2001) in the cortex than in the medulla tissues and because the strawberry surface is normally more affected by water loss than the internal tissues, ascorbic acid and anthocyanin degradation might have been accentuated in unwrapped samples that suffered greater water loss.

\section{Total soluble phenolics}

Total soluble phenolics decreased with storage time in both

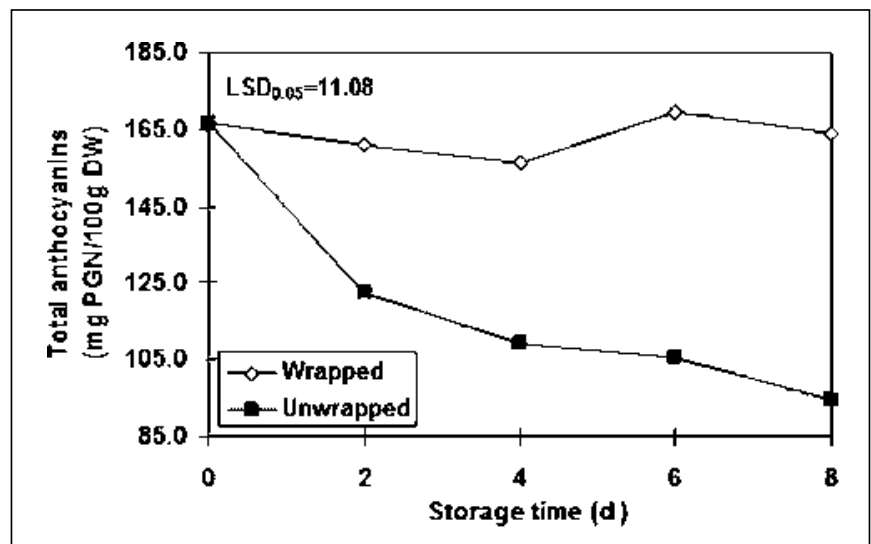

Figure 2-Total anthocyanin content of strawberry fruit stored at $1{ }^{\circ} \mathrm{C}$ for $8 \mathrm{~d}$

Vol. 70, Nr. 1, 2005-JOURNAL OF FOOD SCIENCE 
wrapped and unwrapped strawberries harvested fully red (Figure 3 ). The decrease was greater in the unwrapped fruit than in the wrapped fruit and soluble phenolic content remained lower in unwrapped fruit from days 2 through 8 . After $8 \mathrm{~d}$ of storage, the total phenolics content in unwrapped fruit was $35 \%$ lower than in wrapped fruit. The normal ripening processes of nondamaged fruit bring on changes in the cell membrane permeability, in phenolic metabolism, and in PPO properties. As strawberry fruit senesce, more PPO enzyme becomes soluble, and there is greater development of superficial browning, which may be also attributable to nonenzymatic reactions, such as the formation of iron-phenolic complexes (Lattanzio 2003). The significant loss of water suffered by the unwrapped strawberries compared with the wrapped fruit might have hastened the normal ripening process and contributed to a greater decrease in phenolic content in the former, presumably as a result of enzymatic oxidation. Jiang and Fu (1999a) reported that the total soluble phenolics content in the skin of litchi fruit decreased during storage time and was lower in fruit stored under low RH than in those stored under higher RH. Declining total soluble phenolic content during strawberry fruit maturation and ripening has been reported previously (Cheng and Breen 1991). Spayd and Morris (1981) also reported that total phenolics were higher in ripe-harvested 'Cardinal' strawberries (well-developed red color) than in fruit harvested at the more advanced processing ripe stage (dark red color, slightly soft). The decrease in total soluble phenolics observed in the present study might be at least partly a consequence of the degradation (that is, coupled oxidation) of anthocyanins. In fact, relative losses in total anthocyanins were similar to losses in total soluble phenolics within each treatment (that is, losses in anthocyanins and total soluble phenolics were approximately $3 \%$ and $11 \%$ in wrapped fruit, and about $44 \%$ and $42 \%$ in unwrapped fruit, respectively). The higher quantitative decrease in total soluble phenolics compared with total anthocyanins in the wrapped strawberries might indicate that losses of other non-anthocyanin phenolics that are present in strawberry fruit (Pilando and others 1985; Jerch and others 1989) possibly contributed to this decline during storage.

\section{Polyphenol oxidase activity}

Polyphenol oxidase activity increased during storage in both wrapped and unwrapped strawberries (Figure 4), but was significantly greater in unwrapped than wrapped samples after 4 or more days in storage $(P<0.05)$. Jiang and $\mathrm{Fu}(1999 \mathrm{~b})$ also reported an increase in PPO activity in the skin of litchi fruit stored under reduced RH due to desiccation. In fact, injury and stress have been

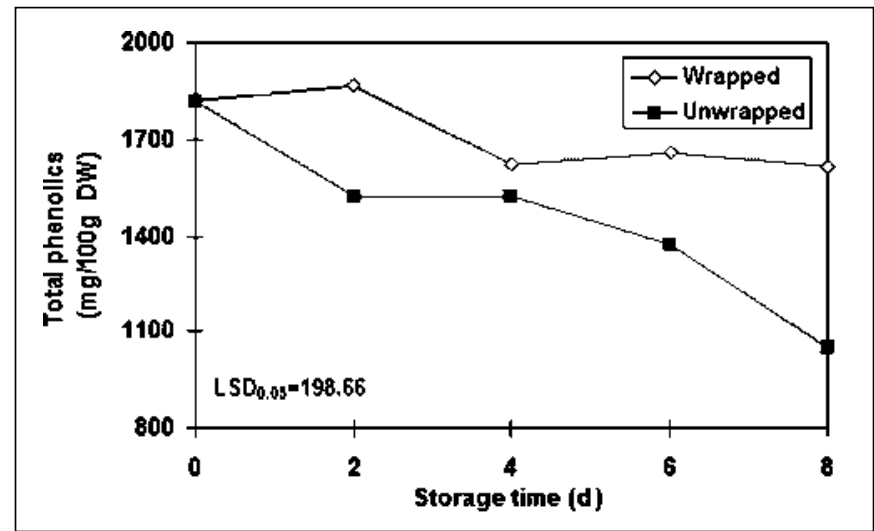

Figure 3-Total soluble phenolics content of strawberry fruit stored at $1{ }^{\circ} \mathrm{C}$ for $8 \mathrm{~d}$ shown to induce PPO activity in many plants (Mayer and Harel 1979; Mayer 1987). Water loss and the consequent loss of turgor pressure, which is manifested as shriveling and wilting, have been shown in many plant systems to lead to increased permeability of the plasmalemma and tonoplast membranes (Leopold and others 1981; Ben-Yehoshua and others 1983; Walter and others 1990; Shibairo and others 2002). Thus, the higher PPO activity observed for unwrapped strawberries in the present study might be attributed to the stress of water loss in those fruit, with possible membrane damage leading to release or induction of the enzyme.

Litchi is an example of a fruit for which browning is a serious problem during storage. Zhang and others (2000) suggested that as storage duration is extended and tissue senescence proceeds, fruit cells gradually lose membrane system integrity, resulting in loss of compartmentation of enzymes and substrates, allowing the enzymes to act on their substrates. Jiang and Fu (1999b) proposed that the rapid increase of electrolyte leakage in litchi fruit during storage as a result of loss of membrane system integrity resulted in phenolic compounds leaking from the vacuoles, mixing with PPO in the cytoplasm, and thus accelerating the degradation of anthocyanins. In another study, Zhang and Quantick (2000) reported that PPO activity in litchi fruit increased during storage to the highest levels found at any point in fruit development, while the total soluble phenolics decreased continuously, corresponding to reactions of enzyme with substrates and leading to the browning of the fruit.

It is possible that accelerated water loss, which has been shown to accelerate senescence processes in plant tissues (Ben-Yehoshua and Rodov 2003), had a similar effect on the strawberries in this study as that previously reported for litchi. The increase in weight loss and PPO activity concurrently with the decrease in anthocyanins and total soluble phenolics, particularly in unwrapped fruit (Figure 2 to 4), might have resulted from accelerated senescence of fruit caused by excessive loss of water from the cells during storage, resulting in PPO, anthocyanins, and other phenolics being released due to cell decompartmentation, and coming into contact with each other. Thus, the oxidation by PPO of phenolic compounds present naturally in the strawberry fruit might have led to the formation of $o$-quinones, which stimulated the anthocyanin degradation by coupled oxidation mechanisms (anthocyanin-PPOphenolic reactions).

Overall, the decrease in anthocyanin and total soluble phenolics

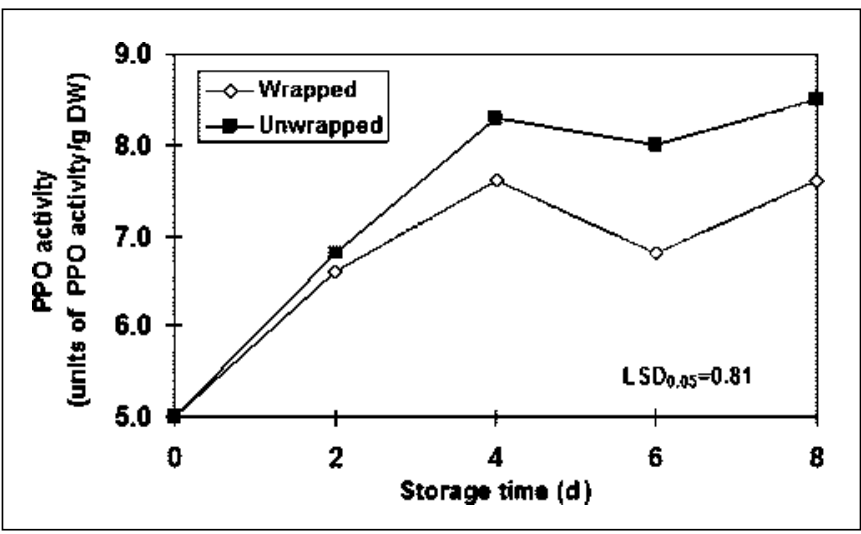

Figure 4-Polyphenol oxidase (PPO) activity in strawberry fruit stored at $1{ }^{\circ} \mathrm{C}$ for $8 \mathrm{~d}$. One unit of PPO activity equals an increase of 0.1 absorbancy unit in $1 \mathrm{~min}$ by a solution obtained by extracting $100 \mathrm{mg}$ acetone powder from strawberry homogenate in $50 \mathrm{~mL} 0.1 \mathrm{M}$ citric acid-0.2 M phosphate buffer (pH 6.2) 
content in unwrapped strawberries during storage might be attributed to the increase in PPO activity during storage, which was higher in unwrapped samples. Spayd and others (1982) reported that addition of PPO to strawberry puree resulted in a rapid loss of red color. Wesche-Ebeling and Montgomery (1990) studied the PPO activity in 'Tioga' strawberries and its contribution to anthocyanin degradation, and concluded that, in fact, the enzyme has an important, although indirect, role in anthocyanin degradation, suggesting that anthocyanins are degraded via oxidation by PPO-produced quinones and other intermediate oxidation products as well as by copolymerization reactions with tannins. López-Serrano and Barceló (2001) suggested that the higher pigment stability in 'Chandler' compared with 'Oso Grande' strawberry could be explained not only by a lower PPO but also by a lower peroxidase and (+)-catechin content. Therefore, a combination of several factors rather than a single one might have contributed to the decrease in the pigment content of unwrapped 'Oso Grande' strawberries during storage.

\section{Browning index and anthocyanin degradation index}

Browning of strawberries expressed as the BI of the juice increased significantly during storage (Figure 5), but no significant difference was noticed between wrapped and unwrapped samples $(P>0.05)$. The BI used in this study as a measure of browning might not be a good indicator of the development of superficial browning during storage of strawberry because it did not reflect the differences observed in the anthocyanin and total soluble phenolics content between treatments.

The ADI, measured as the ratio of the absorbance at the anthocyanin maximum wavelength $(520 \mathrm{~nm})$ to the absorbance at the polymeric pigment (tannin) maximum $(420 \mathrm{~nm})$, indicates the relative amounts of red and brown pigments in a sample and tends to be greater in fresh fruit than in processed or stored samples (Wrolstad 1976). In the present study, the ADI of the strawberry juice tended to decrease with increasing storage time, and a small but significant difference was noticed between wrapped and unwrapped samples after $8 \mathrm{~d}$ of storage $(P>0.05)$ (Figure 5), indicating that a higher amount of anthocyanins was lost in unwrapped fruit compared with wrapped fruit. Although the decrease in ADI values seems to reflect the decrease in total anthocyanin content, the change in $L^{*}$ value, and the increase in superficial browning during storage of unwrapped strawberries, the same does not seem to be true for the wrapped fruit where the decrease in anthocyanins and total soluble phenolics was much lower. Besides the higher content of phenolic

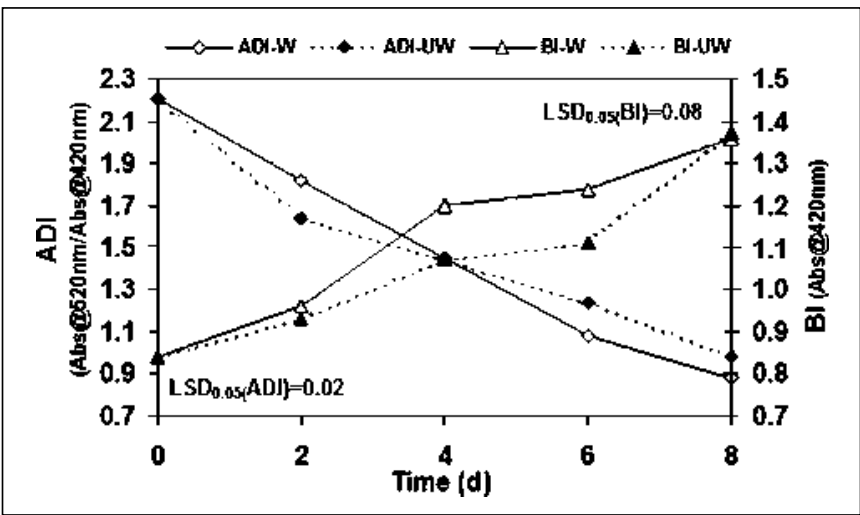

Figure 5-Browning index (BI) and anthocyanin degradation index (ADI) measured on the juice strawberry stored at $1{ }^{\circ} \mathrm{C}$ for $8 \mathrm{~d}$. $\mathrm{W}=$ wrapped, UW = unwrapped compounds, visual observations clearly indicated less appearance of browning in wrapped than unwrapped strawberries. Therefore, the $\mathrm{BI}$ and $\mathrm{ADI}$ used in the present study might not be have been good indicators of superficial browning and anthocyanin degradation, at least when minor superficial changes occurred. More conclusive results might have been obtained if only the cortex of the fruit were used to measure these 2 parameters instead of using the juice from the whole fruit, as changes in color of the fruit seemed to be more pronounced in the outer than in the inner tissues.

\section{Conclusions}

$\mathrm{P}$ igment degradation caused by increased PPO activity as a result of physiological stress due to water loss might contribute to the development of strawberry surface browning during storage. Water loss is one of the major factors that contribute to changes in color of stored strawberries, and it plays an important role in anthocyanin degradation. Water loss accelerates senescence of the fruit, leading to membrane degradation and release of PPO and ascorbate oxidase substrates from the vacuole, leading in this way to oxidation of the cellular components. Because partially ripe strawberries are able to develop normal red color during storage, harvesting the fruit at early stages of color development (about three-quarter colored) should avoid the undesirable color changes observed in stored, full-ripe fruit. Furthermore, proper handling of the strawberries to reduce water loss during postharvest operations, such as prompt precooling, adequate packaging, and storage at optimum temperature and $\mathrm{RH}$, should also help maintain acceptable color during shipping and retailing. Additional research on the development of superficial browning of strawberries during storage at optimum temperatures needs to consider several factors other than those evaluated in the present study. Factors that could also have an influence on the development of dark-colored pigments include changes in ascorbic acid and in sugar profiles, peroxidase activity, and other phenolic compounds that are good substrates for enzymatic browning.

\section{Acknowledgements}

This research was supported by the Florida Agricultural Experiment Station and a grant from JNICT (Junta Nacional de Investigação Científica e Tecnológica, Portugal), and approved for publication as Journal Series Nr R-10042. We thank Al Herndon of Ferris Farms, Floral City, Florida, for his cooperation in conducting this research.

\section{References}

Bakker J, Bridle P, Bellworthy SJ. 1994. Strawberry juice color: A study of the quantitative and qualitative pigment composition of juices from 39 genotypes. J Sci Food Agric 64(1):31-7.

Bender AE. 1978. Food processing and nutrition. Food Science and Technology, a Series of Monographs. London: Academic. 243 p.

Ben-Yehoshua S, Rodov V. 2003. Transpiration and water stress. In: Bartz JA Brecht JK, editors. Postharvest physiology and pathology of vegetables. 2nd ed. New York: Marcel Dekker. p 111-59.

Ben-Yehoshua S, Shapiro B, Even-Chen Z, Lurie S. 1983. Mode of action of plastic film in extending life of lemon and bell pepper fruits by alleviation of water stress. Plant Physiol 73(1):87-93.

Cheng GW, Breen PJ. 1991. Activity of phenylalanine ammonia-lyase (PAL) and concentrations of anthocyanins and phenolics in developing strawberry fruit. J Amer Soc Hort Sci 116(5):865-9.

Flurkey WH, Jen JJ. 1978. Peroxidase and polyphenol oxidase activities in developing peaches. J Food Sci 43(6):1826-31.

Folin D, Ciocalteu V. 1927. On tyrosine and tryptophane determinations in proteins. J Biol Chem 73(2):627-50.

Francis FJ. 1980. Color quality evaluation of horticultural crops. HortScience 15(1):58-9

Holcroft DM, Kader AA. 1999. Controlled atmosphere-induced changes in pH and organic acid metabolism may affect color of stored strawberry fruit. Postharv Biol Technol 17(1):19-32.

Jackman RL, Yada Ry, Tung MA, Speers RA. 1987. Anthocyanins as food colorantsa review. J Food Biochem 11(3):201-47.

Jerch S, Scherer C, Huth G, Schlosser E. 1989. Proanthocyanidins as basis for 
quiescence of Botrytis cinerea in immature strawberry fruits. J Plant Dis Protect 96(4):365-78.

Jiang Y. 2000. Role of anthocyanins, polyphenol oxidase and phenols in lychee pericarp browning. J Sci Food Agric 80(3):305-10.

Jiang YM, Fu JR. 1999a. Biochemical and physiological changes in browning of litchi fruit caused by water loss. J Hort Sci Biotechnol 74(1):43-6.

Jiang YM, Fu JR. 1999b. Postharvest browning of litchi fruit by water loss and its prevention by controlled atmosphere storage and high relative humidity. Lebensm Wiss Technol 32(5):278-83.

Kader F, Nicolas J-P, Metche M. 1999. Degradation of pelargonidin 3-glucoside in the presence of chlorogenic acid and blueberry polyphenol oxidase. J Sci Food Agric 79(4):517-22.

Kader F, Rovel B, Girardin M, Metche M. 1997. Mechanism of browning in fresh highbush blueberry fruit (Vaccinium corymbosum $\mathrm{L}$ ). Role of blueberry polyphenol oxidase, chlorogenic acid and anthocyanins. J Sci Food Agric 74(1):31-4.

Kalt W, Prange RK, Lidster PD. 1993. Postharvest color development of strawberries: Influence of maturity, temperature and light. Can J Plant Sci 73(4):541-8.

Leopold A, Musgrave M, Williams K. 1981. Solute leakage resulting from leaf desiccation. Plant Physiol 68(6):1222-5.

López-Serrano M, Ros Barceló A. 2001. Histochemical localization and developmental expression of peroxidase and polyphenol oxidase in strawberries. J Amer Soc Hort Sci 126(1):27-32.

Mayer AM, Harel E. 1979. Polyphenol oxidases in plants. Phytochemistry 18(2): 193-215.

Mayer AM. 1987. Polyphenol oxidases in plants-recent progress. Phytochemistry $26(1): 11-20$.

Miszczak A, Forney CF, Prange RK. 1995. Development of aroma volatiles and color during postharvest ripening of 'Kent' strawberries. J Amer Soc Hort Sci $120(4): 650-655 ; 882$ (errata).

Nicolas JJ, Richard-Forget FC, Goupy PM, Amiot M-J, Aubert SY. 1994. Enzymatic browning reactions in apple and apple products. Crit Rev Food Sci Nutr 34(2):109-57.

Nunes MCN. 1995. Physiology of strawberry fruits during ripening and as influenced by postharvest temperature and atmosphere [Dphil thesis]. Porto, Portugal: Escola Superior de Biotecnologia da Univ. Católica Portuguesa, Portugal. 280 p. Available from: Escola Superior de Biotecnologia da Univ. Católica Portuguesa, Portugal. http://www2.esb.ucp.pt/twt/esb graduados/. Accessed Jan 10,2005

Nunes MCN, Brecht JK, Morais AMMB, Sargent SA. 1995a. Physical and chemical quality characteristics of strawberries after storage are reduced by a short delay to cooling. Postharv Biol Technol 6(1):17-28.
Nunes MCN, Brecht JK, Sargent SA, Morais AMMB. 1995b. Effects of delays to cooling and wrapping on strawberry quality (cv. Sweet Charlie). Food Control $6(6): 323-8$

Nunes MCN, Brecht JK, Sargent SA, Morais AMMB. 1998. Controlling temperature and water loss to maintain ascorbic acid levels in strawberries during postharvest handling. J Food Sci 63(6):1033-6.

Pilando LS, Wrolstad RE, Heatherbell DA. 1985. Influence of fruit composition, maturity and mold contamination on the color and appearance of strawberry wine. J Food Sci 50(4):1121-5.

Robinson JE, Browne KM, Burton WG. 1975. Storage characteristics of some vegetables and soft fruits. Ann. Appl. Biol. 81(3):399-408.

Sacks EJ, Shaw DV. 1993. Color change in fresh strawberry fruit of seven genotypes stored at $0{ }^{\circ} \mathrm{C}$. HortScience $28(3): 209-10$.

SAS Inst. 1982. SAS user's guide: Statistics. Cary, N.C.: SAS Inst. Inc.

Shibairo SI, Upadhyaya MK, Toivonen PMA. 2002. Changes in water potential, osmotic potential, and tissue electrolyte leakage during mass loss in carrots stored under different conditions. Sci Hort 95(1-2):13-21.

Singleton VL, Rossi JA. 1965. Colorimetry of total phenolics with phosphomolybdic-phosphotungistic acid reagents. Amer J Enol Viticult 16(3):144-57.

Spanos GA, Wrolstad RE. 1992. Phenolics of apple, pear, and white grape juices and their changes with processing and storage-a review. J Agric Food Chem 40(9):1478-87.

Spayd SE, Morris JR. 1981. Effects of immature fruit and holding on strawberry puree and color stability. J Amer Soc Hort Sci 106(1):211-6.

Spayd SE, Morris JR, Robert CL. 1982. Influence of peroxidase and polyphenol oxidase on the color of puree from machine-harvested strawberries. J Amer Soc Hort Sci 107(6):1070-3.

Talasila PC, Chau KV, Brecht JK. 1995. Modified atmosphere packaging under varying surrounding temperature. Trans ASAE 38(1):869-76.

Walter WM, Epley DG, McFeeters RF. 1990. Effects of water-stress on stored pickling cucumbers. J Agric Food Chem 38(12):2185-91.

Wesche-Ebeling P, Montgomery MW. 1990. Strawberry polyphenoloxidase: Its role in anthocyanin degradation. J Food Sci 55(3):731-4, 745.

Wrolstad RE. 1976. Color and pigment analyses in fruit products. Station Bulletin No. 624, Agric. Exp. Station, Oregon State Univ., Corvallis, Ore., U.S.A

Zhang D, Quantick PC, Grigor JM. 2000. Changes in phenolic compounds in litch (Litchi chinensis Soon.) fruit during postharvest storage. Postharv Biol Technol 19(2):165-72.

Zhang DL, Quantick PC. 2000. Changes of phenolics of litchi fruit during postharvest storage. Acta Hort 517:427-33. 